\title{
Joint degree program Finance and Accounting for Common Europe
}

\author{
Marie Míková*
}

Fakulta financí a účetnictví (FFÚ) na Vysoké škole ekonomické v Praze obdržela koncem roku 2005 z EU potvrzení o koordinaci joint degree programu Finance and Accounting for Common Europe. Jedná se o navazující magisterský studijní program, jehož hlavním cílem je přidat magisterskému studijnímu programu v oblasti financí a účetnictví evropskou dimenzi v oblasti studijního plánu (curriculum). Program odpovídá svým obsahovým zaměřením dnešním potřebám studijních programů typu ,joint degree“. Zájemci o studium v tomto programu by měli být především absolventi bakalářského studijního programu oborů finance, účetnictví či podobných ekonomických disciplín. Program bude připravovat studenty pro manažerské pozice v účetnictví, v bankách, na kapitálových trzích, v daňové oblasti apod.

Joint degree program Finance and Accounting for Common Europe byl vytvořen ve spolupráci čtyř evropských vysokých škol. Program umožňuje rozvoj zkušeností a tradic různých evropských zemí. Každá vysoká škola přispívá svým specifickým zaměřením a zkušenostmi.

- FFÚ zajišt'uje teoretický základ zvláště v oblasti podnikových financí, manažerského účetnictví a veřejných financí,

- University of Ljubljana (UL) teoretický základ a praktickou aplikaci v oblasti veřejné správy a neziskového sektoru,

- Rotterdam Business School (RBS) teoretický základ a praktickou aplikaci v oblasti manažerského řízení a osobního rozvoje studentů,

- Universita Mateje Bela, Banská Bystrica (UMB) teoretický základ v oblasti mikroekonomie a makroekonomie.

Program bude implementován na všech čtyřech vysokých školách a vyučován $\mathrm{v}$ anglickém jazyce. Studium je rozděleno do dvou let. Studenti budou rozvíjet své znalosti a dovednosti, komunikovat a spolupracovat při řešení týmových úkolů. Velký důraz je kladen také na osobní rozvoj studentů a etické normy. Studenti budou stimulováni používat v programu kreativní metody, bude rozvíjena jejich schopnost dojít k určitým závěrům a tyto umět obhájit. Snahou programu je rozvoj ekonomického myšlení studentů od schopnosti aplikace $\mathrm{v}$ teoretické úrovni až $\mathrm{k}$ praktické aplikaci $\mathrm{v}$ oblasti účetnictví a financí. V programu proto bude více specializovaných seminářŭ, které budou zaměřeny na týmovou práci v rámci specializovaných projektů.

Předměty jsou rozděleny zhruba do čtyř oblastí:

- účetnictví a finanční management,

- bankovnictví a monetární politika,

- veřejné finance a neziskové organizace,

- ekonomie.

Doc. Ing. Marie Míková, CSc. - proděkanka pro pedagogickou a studijní činnost, docentka; Katedra finančního účetnictví, Fakulta financí a účetnictví, Vysoká škola ekonomická v Praze, nám. W. Churchilla 4, 13067 Praha 3; <mikova@vse.cz>. 


\section{Struktura programu: Finance and Accounting for Common Europe}

Studenti v magisterském studijním programu musí získat 120 ECTS. 60 ECTS získají za jednotlivé předměty absolvované na třech vysokých školách (FFÚ, UMB a RBS). Ve druhém roce musí na své mateřské vysoké škole zpracovat tři výzkumné projekty. Jeden projekt je zaměřen na specifickou oblast financí, druhý na specifickou oblast účetnictví a třetí na specifickou oblast veřejných financí. Témata budou zadávána garanty projektů.

Studijní program je dvouletý a budou se na něm podílet čtyři vysoké školy. University of Ljubljana se bude na programu podílet hostujícími profesory. Ve druhém roce studia musí studenti také obhájit svoji diplomovou práci.

\begin{tabular}{lrl} 
Povinné kurzy: & $7 \cdot 6$ ECTS (UMB 2, FFÚ 3, RBS 2) \\
Personal Development Plan: & $3 \cdot 3$ ECTS (bude zabezpečovat RBS) \\
Volitelné kurzy: & $3 \cdot 3$ ECTS \\
Výzkumný projekt: & $3 \cdot 10$ ECTS \\
Diplomová práce: & 30 ECTS \\
\hline Celkem: & 120 ECTS
\end{tabular}

1. rok

\begin{tabular}{|c|c|c|c|c|}
\hline semestr & od - do & $\begin{array}{l}\text { počet } \\
\text { měsíců }\end{array}$ & ECTS & vysoká škola \\
\hline 1 & $\begin{array}{l}\text { polovina prosince } \\
\text { - polovina ledna }\end{array}$ & 3 & 18 & $\begin{array}{l}\text { Universita Mateje Bela, } \\
\text { Banská Bystrica }\end{array}$ \\
\hline 2 & leden - březen & 3 & 24 & $\begin{array}{l}\text { Fakulta financí a účetnictví } \\
\text { Vysoká škola ekonomická } \\
\text { v Praze }\end{array}$ \\
\hline \multirow[t]{2}{*}{3} & duben - červen & 3 & 18 & Rotterdam Business School \\
\hline & celkem & 10 & 60 & \\
\hline
\end{tabular}

2. rok

\begin{tabular}{|c|c|c|c|c|}
\hline semestr & od - do & $\begin{array}{l}\text { počet } \\
\text { měsíců }\end{array}$ & ECTS & domácí vysoká škola \\
\hline 1 & záấí - ř́ijen & 2 & 10 & výzkumný projekt 1 \\
\hline 2 & listopad - prosinec & 2 & 10 & výzkumný projekt 2 \\
\hline 3 & leden - únor & 2 & 10 & výzkumný projekt 3 \\
\hline \multirow[t]{2}{*}{4} & březen - červen & 4 & 30 & obhajoba diplomové práce \\
\hline & celkem & 10 & 60 & \\
\hline
\end{tabular}

Personal Development Plan - zde jsem použila anglický výraz, nebot' nenacházím žádný vhodný český výraz. Překlad „plán osobního rozvoje“ se mi nejeví jako nejšt’astnější. Navíc je to předmět, se kterým mají zkušenosti univerzity $\mathrm{v}$ západních zemích. U nás se zatím předměty tohoto typu nevyučují. To byl také důvod k tomu, že výuku tohoto předmětu budou zajišt'ovat pedagogové z Rotterdamu. 
Témata výzkumných projektů budou zadávat garanti těchto projekti̊. Studentům bude umožněno zpracovávat svůj výzkumný projekt v konkrétním podniku. Mohou projekt zpracovávat samostatně nebo v týmu. Předpokládá se hlavně týmová práce.

Fakulta financí a účetnictví VŠE v Praze zkompletovala akreditační spis joint degree programu Finance and Accounting for Common Europe a předložila jej začátkem října 2006 Akreditační komisi MŠMT k posouzení. Akreditační komise MŠMT na svém ř́ijnovém zasedání udělila akreditaci tomuto programu. Výuka studentů tedy začne zkušebně v akademickém roce 2007/2008. 


\title{
Joint degree program Finance and Accounting for Common Europe
}

Marie Míková

\begin{abstract}
ABSTRAKT
Článek poskytuje informace o novém studijním programu tzv. joint degree s názvem Finance and Accounting for Common Europe, který se začne vyučovat na Fakultě financí a účetnictví Vysoké školy ekonomické v Praze od akademického roku 2007/2008.
\end{abstract}

Klíčová slova: Joint degree program; Studijní program.

\section{Joint degree program Finance and Accounting for Common Europe}

\begin{abstract}
Paper provides information about a new study program - a joint degree program Finance and Accounting for Common Europe, which will be taught at the Faculty of Finance and Accounting, University of Economics, Prague for the first time in academic year 2007/2008.
\end{abstract}

Key words: Joint degree program; Study program.

JEL classification: M41 